\title{
PENERAPAN MODEL TIME TOKEN ARENDS UNTUK MENINGKATKAN HASIL BELAJAR PADA PEMBELAJARAN PKN SISWA KELAS IV SDN TUNJUNGTIRTO 02
}

\author{
Susilowati \\ Sekolah Dasar Negeri 2 Tunjungtirto \\ Kecamatan Singosari, Kabupaten Malang \\ E-mail : susilowati.tunjungtirto@gmail.com
}

\begin{abstract}
The purpose of this research is to describe the application of Cooperative Time Token Arends learning model to increase learning outcomes of fourth grade students of SDN Tunjungtirto 02, Singosari. This research uses Classroom Action Research (PTK) with 2 (two) cycles. The subjects of this study were 16 students of grade IV SDN Tunjungtirto 02 Singosari. Data collection techniques in this study are observation, interviews, documentation, and tests. The technique to analyze the data used in this research is descriptive qualitative analysis technique. The results show that learning by applying the Time Token Arends Cooperative model on the subject of globalization can increase learning outcomes. Student learning outcomes also experienced an average increase from cycle I (72.12) to cycle II (76.9). Classical mastery increased by $12.5 \%$ from cycle I to cycle II.
\end{abstract}

Key Words: time token arends model; activity; learning outcomes; PKn

\begin{abstract}
ABSTRAK
Tujuan dalam penelitian ini adalah mendeskripsikan terhadap peningkatan hasil belajar siswa kelas IV SDN Tunjungtirto 02 Kecamatan Singosari Kabupaten Malang pada mata pelajaran PKn. Penelitian ini menggunakan jenis Penelitian Tindakan Kelas (PTK) dengan 2 (dua) siklus. Subyek penelitian ini adalah 16 siswa kelas IV SDN Tunjungtirto 02 Singosari. Teknik pengumpulan data dalam penelitian ini adalah observasi, wawancara, dokumentasi, dan tes. Adapun teknik untuk menganalisis data yang digunakan dalam penelitian ini adalah teknik analisis deskriptif kualitatif. Hasil penelitian menunjukkan bahwa pembelajaran dengan menerapkan model Kooperatif Time Token Arends pada pokok bahasan globalisasi dapat meningkatkan hasil belajar siswa. Hasil belajar siswa juga mengalami peningkatan rata-rata dari siklus I $(72,12)$ ke siklus II $(76,9)$. Ketuntasan klasikal meningkat sebanyak $12,5 \%$ dari siklus I ke siklus II.
\end{abstract}

Kata Kunci: model time token arends; aktifitas; hasil belajar; PKn

\section{PENDAHULUAN}

Pendidikan Kewarganegaraan (PKn) merupakan suatu mata pelajaran yang diajarkan pada setiap jenjang pendidikan di Indonesia, mulai dari Sekolah Dasar (SD) sampai dengan Sekolah Menengah Atas (SMA). Khusus untuk mata pelajaran PKn, selain bertujuan untuk menjadikan warga negara yang baik, yaitu warga negara yang tahu, mau, dan sadar akan hak dan kewajibannya, juga diharapkan kelak dapat menjadi bangsa yang terampil, cerdas, demokratis dan bersikap baik sehingga mampu mengikuti kemajuan teknologi modern. Suharjo (2006:1) menyatakan PKn ini perlu diajarkan di SD dengan maksud untuk memberikan bekal kemampuan dasar kepada siswa 
berupa pengetahuan, keterampilan, dan sikap yang bermanfaat bagi dirinya sesuai dengan tingkat perkembangannya, karena jenjang SD merupakan jenjang pertama pendidikan jalur persekolahan

Guru mempunyai tugas untuk memilih model, metode dan media pembelajaran yang tepat dan sesuai dengan materi yang disampaikan demi tercapainya tujuan pembelajaran. Sampai saat ini masih banyak ditemui berbagai masalah dalam pembelajaran PKn. Salah satunya adalah adanya ketidak aktifan siswa dalam mengikuti kegiatan belajar mengajar khususnya pada mata pelajaran PKn. Siswa sekedar mengikuti pelajaran PKn yang diajarkan guru di dalam kelas, yaitu hanya dengan mendengarkan ceramah dan mengerjakan soal yang diberikan oleh guru tanpa adanya respon, kritik, dan pertanyaan dari siswa kepada guru sebagai feed back atau umpan balik dalam kegiatan pembelajaran. Siswa lebih banyak pasif dalam mengikuti kegiatan pembelajaran. Situasi yang demikian mengakibatkan keinginan siswa untuk mengikuti kegiatan pembelajaran mata pelajaran PKn cenderung menurun, aktivitas siswa dalam kegiatan pembelajaran cenderung kurang diperhatikan.

Berdasarkan hasil observasi yang dilakukan guru di kelas IV SDN Tunjungtirto.02, pembelajaran yang biasa dilaksanakan oleh guru mata pelajaran PKn adalah pembelajaran konvensional, hanya dengan menggunakan metode ceramah dan pemberian tugas. Dalam kegiatan belajar siswa bekerja secara individu, ada yang hanya pasif dalam kegiatan pembelajaran ada juga yang aktif dalam kegiatan pembelajaran. Anak yang aktif dalam pembelajaran biasanya selalu mendominasi kelas. Sebenarnya, proses pembelajaran yang dirancang oleh guru sudah dirancang secara sistematis dan maksimal, namun setelah diterapkan dalam kegiatan pembelajaran hasilnya masih kurang efektif. Hal tersebut yang diduga menjadi penghambat dalam proses pembelajaran dan mengakibatkan hasil belajar yang diperoleh siswa tidak mencapai standart ketuntasan minimal yang ditetapkan sekolah yaitu 65 .

Paradigma semacam itu harus bergeser ke arah pembelajaran yang berorientasi pada memposisikan siswa sebagai pelaku utama dalam kegiatan pembelajaran. Agar tujuan tersebut dapat tercapai, maka peran guru perlu dialihkan dari peran dominan di kelas menjadi "fasilitator belajar". Peran ini dapat membuat siswa terlibat secara aktif dalam proses pembelajaran dan memperoleh sesuatu dari hasil belajarnya. Mengajar bukan hanya menyampaikan bahan pembelajaran pada siswa, tetapi merupakan suatu proses upaya dalam membimbing dan memfasilitasi siswa supaya dapat belajar secara efektif dan efisien. Keberhasilan pembelajaran sangat dipengaruhi oleh proses pembelajaran yang dikembangkan oleh guru, oleh karena itu guru harus memiliki kemampuan dalam memilih, mengembangkan dan menerapkan model pembelajaran dan berbagai metode yang tepat untuk mencapai tujuan pembelajaran.

Untuk kepentingan pembelajaran PKn di SD, digunakan berbagai alternatif model pembelajaran, baik untuk tujuan kognitif, afektif dan psikomotor. Banyak model pembelajaran yang dapat diterapkan untuk pembelajaran PKn. Akan tetapi tidak semua model tersebut dapat cocok untuk pembelajaran PKn di SD. Guru harus dapat memilih model yang tepat sesuai dengan tujuan pembelajaran sehingga tujuan pembelajaran yang dirumuskan oleh guru dapat tercapai secara maksimal sehingga hasil belajar siswa dapat mencapai standart ketuntasan minimal yang diharapkan yaitu nilai 65, model pembelajaran kooperatif time token arends adalah salah satu alternatif model pembelajaran yang cocok untuk digunakan dalam proses pembelajaran PKn di SD. Aktifitas pembelajaran siswa lebih efektif dan hasil belajar siswa lebih baik dari yang diperoleh dari sebelumnya.

Model pembelajaran kooperatif Time Token Arends merupakan model pembelajaran yang bertujuan agar masing-masing anggota kelompok diskusi mendapatkan kesempatan untuk memberikan konstribusi mereka dan mendengarkan pandangan serta pemikiran anggota lain. 
Model pembelajaran kooperatif Time Token Arends cocok digunakan oleh guru PKn untuk menyampaikan materi tentang globalisasi. Materi ini perlu ditanamkan oleh guru kepada anak SD supaya siswa dapat mengerti tentang globalisasi sehingga siswa dapat menentukan sikap yang tepat dalam menghadapi dampak dari globalisasi. Model pembelajaran kooperatif Time Token Arends memungkinkan siswa untuk aktif dalam mengikuti kegiatan pembelajaran. Model ini dapat membantu guru dalam mengelola kelas misalnya, apabila seorang guru memiliki kelompok cooperatife learning dengan beberapa orang mendominasi pembicaraan dan beberapa orang pemalu dan tidak pernah mengatakan apa-apa, time tokens dapat mendistribusikan partisipasi dengan lebih merata sehingga memungkinkan siswa untuk melatih ketrampilan sosialnya misalnya, berlatih untuk berpendapat serta memberikan kesempatan kepada siswa lain untuk menyampaikan pendapat, dan berlatih menghargai pendapat yang dimiliki oleh siswa lain. Selain itu juga dapat meningkatkan ketrampilan berbicara setiap siswa. Berdasarkan uraian tersebut, maka perlu diadakan penelitian untuk mengetahui penerapan model Time Token Arends terhadap hasil belajar Globalisasi pada mata pelajaran PKn Siswa Kelas IV SDN Tunjungtirto 02 Singosari.

\section{METODE PENELITIAN}

Jenis penelitian yang digunakan dalam penelitian ini adalah Penelitian Tindakan Kelas. PTK (classroom action research) yaitu penelitian yang dilakukan oleh guru ke kelas atau sekolah tempat dia mengajar dengan penekanan pada penyempurnaan atau peningkatan proses dan praktis pembelajaran (Arikunto, 2010:135). Siklus Penelitian Tindakan Kelas dapat dilihat dalam bagan 1.

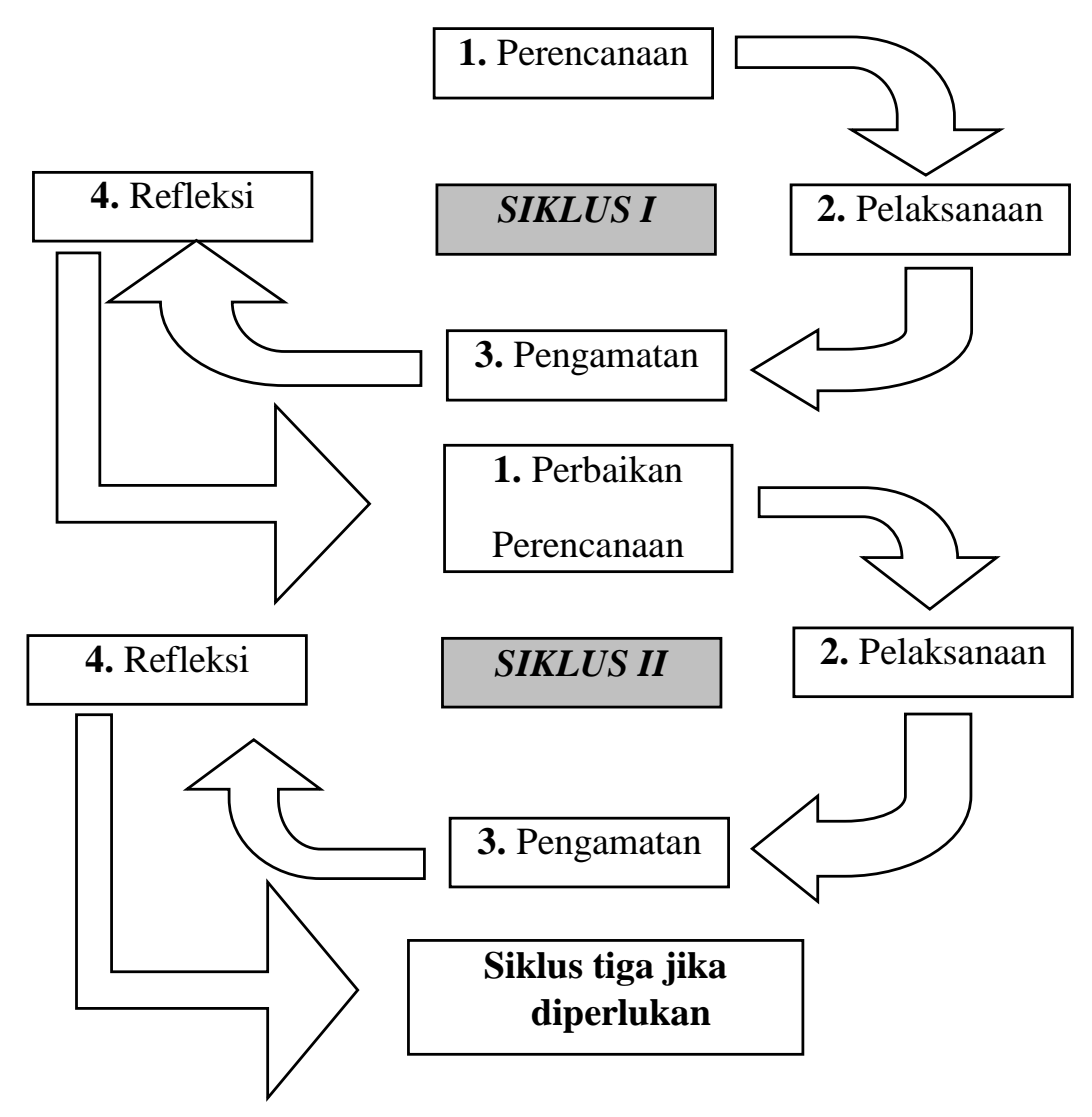

Gambar 1. Skema Siklus dalam PTK Kemmis dan Taggart (dalam Arikunto, 2010:137) 
Penelitian ini dilakukan di SDN 02 Tunjungtirto Kecamatan Singosari, Kabupaten Malang. Kelas yang akan diteliti adalah kelas IV dengan jumlah 20 siswa terdiri dari 12 orang siswa lakilaki dan 8 orang siswa perempuan. Penelitian ini akan dilaksanakan pada bulan Maret 2017. Tahaptahap yang ditempuh dalam penelitian ini mengikuti alur tindakan yang dikemukakan oleh Kemmis dan Mc Tanggart, penelitian ini diawali dengan kegiatan perencanan tindakan, tahap pelaksanaan tindakan, observasi dan refleksi.

\section{SIKLUS I}

Pelaksanaan tahap-tahap pada siklus I terdiri dari perencanaan, pelaksanaan tindakan \& observasi, refleksi dan perbaikan rencana.

1. Tahap Perencanaan Tindakan

Perencanaan tindakan dalam siklus I ini didasarkan pada hasil observasi awal mengenai prestasi belajar siswa. Pada tahap ini kegiatan yang dilakukan oleh peneliti bersama guru Kelas lain: menyusun RPP sesuai materi (terlampir), menyiapkan media yang diperlukan dalam pelaksanaan pembelajaran, merancang atau menyusun soal post tes.

2. Tahap Pelaksanaan Tindakan

Pelaksanaan tindakan yang dimaksud adalah pelaksanaan pembelajaran PKn dengan menggunakan model pempelajaran kooperatif time token arends. Peneliti melaksanakan penelitian tentang pokok bahasan Globalisasi pada mata pelajaran PKn. Peneliti meneliti jalannya pembelajaran dari pembukaan sampai dengan penutup yang tertera pada Rencana Pelaksanaan Pembelajaran (RPP). Pada waktu kegiatan pembelajaran berlangsung, peneliti melakukan observasi dan mencatat semua kejadian selama kegiatan pembelajaran berlangsung. Adapun rencana pembelajaran yang dilaksanakan adalah meliputi kegiatan awal, kegiatan inti, dan kegiatan akhir dengan penerapan model pembelajaran kooperatif time token arend.

3. Tahap Observasi

Observasi dilakukan bersamaan dengan pelaksanaan pembelajaran. Observasi/pengamatan yaitu pelaksanaan pengamatan oleh pengamat. Peneliti melaksanakan observasi dan mencatat semua kejadian selama proses belajar mengajar berlangsung dengan bantuan instrumen observasi. Hasil observasi dapat bermanfaat untuk pengambilan keputusan, apakah siswa dapat memahami materi yang telah diajarkan, apakah perlu dilakukan perbaikan, apakah pembelajaran dapat berlangsung secara aktif sesuai harapan, dan apakah siswa dapat melaksanakan tugas serta dapat menjawab pertanyaan yang diberikan pada saat evaluasi pembelajaran.

4. Tahap Refleksi

Refleksi dilakukan untuk melihat keseluruhan proses pelaksanaan tindakan dan hasil pemahaman siswa. Refleksi dilakukan dengan menganalisis data-data yang diperoleh melalui observasi berupa pedoman pengamatan dan hasil tes. Jika hasil evaluasi pembelajaran pada siklus I sudah sesuai dengan indikator keberhasilan maka pembelajaran telah berhasil, namun jika hasil evaluasi pembelajaran tidak sesuai dengan indikator keberhasilan maka peneliti perlu merencanakan dan melaksanakan tindakan pada siklus berikutnya serta memperbaiki kelemahan yang ada.

\section{SIKLUS II}

Siklus II merupakan kelanjutan dari pelaksanan siklus I. Pelaksanaan tahap-tahap siklus II sama dengan siklus I. Namun, untuk merencanakan tindakan yang akan dilakukan pada siklus II ini, haruslah mengetahui terlebih dahulu hasil dari pelaksanaan siklus I, sehingga belum dapat di 
paparkan secara terperinci rencana pelaksanaannya sebab siklus I belum terlaksana sehingga belum dapat menentukan bentuk rencana perbaikannya.

Jenis data yang hendak dikumpulkan dalam penelitian ini adalah data hasil belajar siswa yang meliputi 3 ranah yaitu afektif, psikomotor, dan kognitif pada pembelajaran PKn. Teknik pengumpulan data dalam penelitian yang dilakukan ini terdiri atas : observasi, wawancara, dan tes. a. Observasi

Teknik observasi digunakan untuk mengamati gejala-gejala yang tampak dalan proses pembelajaran tentang kesungguhan siswa ketika mengikuti pembelajaran, keseringan siswa bertanya, kemauan dan kemampuan siswa menanggapi pertanyaan teman di kelasnya. Selain itu observasi juga digunakan untuk mengamati bagaimana aktivitas siswa dalam mempraktikkan model kooperatif Time Token Arends.

b. Wawancara

Pada saat melakukan wawancara, pewawancara membawa pedoman wawancara yang berisi tentang garis-garis besar hal-hal yang akan ditanyakan. Wawancara yang digunakan dalam penelitian ini adalah wawancara tidak terstruktur dan dilaksanakan secara bebas dan santai.

c. Tes

Menurut Arikunto (2010:193), tes adalah serentetan pertanyaan atau latihan atau alat lain yang digunakan untuk mengukur keterampilan, pengetahuan, intelegensi, kemampuan, atau bakat yang dimiliki oleh individu atau kelompok. Ditinjau dari sasaran atau objek yang akan dievaluasi,maka dibedakan adanya beberapa macam tes dan alat ukur lain. Misalnya, tes prestasi (achievement test).

Analisis data yang digunakan dalam penelitian ini bersifat deskriptif kualitatif. Analisis data ditunjukkan berupa paparan data yang diuraikan dalam bentuk kalimat. Data yang terkumpul akan dianalisis secara deskriptif, baik deskriptif kualitatif maupun deskriptif kuantitatif. Data kualitatif berupa catatan observasi/pengamatan, dokumen foto, catatan lapangan akan dianalisis kualitatif dengan tahapan pemaparan data, penyederhanaan data, pengelompokan data sesuai fokus masalah, pemaknaan dan penyimpulan hasil analisis.

Sedangkan data yang akan dianalisis secara deskriptif kuantitatif adalah data yang terdapat pada pedoman observasi keaktifan siswa yang di wujudkan dalam bentuk tabel berupa "cek list" pada pedoman observasi keaktifan siswa, serta data tentang hasil belajar (kognitif) berupa nilai (score). Analisis data yang bersifat deskriptif kuantitatif dilakukan dengan analisis prosentase dan analisis rata-rata. Untuk memperoleh data yang diperlukan dalam penelitian ini, digunakan analisis data deskriptif dengan menghitung.

\section{Data Hasil Observasi Siswa selama Pembelajaran Berlangsung}

Data tentang aktivitas siswa selama pembelajaran berlangsung dicatat menggunakan panduan observasi terdapat pada lampiran 5. Untuk mengetahui hasil aktivitas siswa selama pembelajaran berlangsung menggunakan rumus:

Keterangan:

$$
\mathrm{NP}=\frac{N}{n m} x 100
$$

NP : Nilai proses aktivitas siswa

$\mathrm{N} \quad$ : Jumlah nilai yang diperoleh pada setiap aspek

nm : Jumlah nilai maksimal semua aspek 


\section{Data Hasil Belajar Siswa}

Analisis data hasil belajar siswa diperoleh dari penskoran hasil tes. Pada siklus I diadakan dua kali tes, kemudian keduanya dicari rata-rata. Begitu juga untuk siklus II, dilakukan dua kali tes yang kemudian keduanya dicari rata-rata. Skor maksimal yang diperoleh siswa 100.

Skor tesnya dapat dihitung melalui rumus:

Keterangan:

$$
\bar{X}=\frac{\sum X}{N}
$$

$\bar{X}=$ nilai rata-rata

$\sum X=$ jumlah skor keseluruhan

$N$ = jumlah siswa (Arikunto, 2009:264)

Sedangkan untuk mengintepretasikan dalam prosentase menggunakan rumus:

Keterangan:

$$
P=\frac{f}{N} X 100 \%
$$

$\mathrm{P}=$ Prosentase

$\mathrm{F}=$ Frekuensi/skor mentah yang dicari prosentasenya

$\mathrm{N}$ = jumlah frekuensi (banyaknya individu) (Sudjono dalam Budiati, 2010:55)

Hasil prosentase dari perhitungan tersebut, kemudian ditetapkan kriterianya. Dalam hal ini kriteria dalam katagori skor siswa bisa dilihat pada tabel 1 berikut:

Tabel 1. Interpretasi hasil belajar

\begin{tabular}{lcl}
\hline No. & Interval Skor & Kualifikasi \\
\hline 1. & $81-100$ & Sangat baik (A) \\
2. & $61-80$ & Baik (B) \\
3. & $41-60$ & Cukup (C) \\
4. & $21-40$ & Kurang (D) \\
5. & $1-20$ & Sangat kurang (E) \\
\hline
\end{tabular}

(dimodifikasi dari Budiati, 2010:55)

Analisis untuk mengetahui peningkatan hasil belajar siswa ditentukan dengan ketuntasan belajar secara individual dan secara klasikal. Kriteria penguasaan minimal belajar yang digunakan dalam penelitian ini adalah secara individual, dianggap telah "tuntas belajar" apabila daya serap siswa mencapai 70. Sedangkan secara klasikal di anggap telah "tuntas belajar" apabila telah mencapai $70 \%$ dari jumlah siswa yang mencapai daya serap minimal 70. Rumus untuk mengetahui ketuntasan belajar adalah sebagai berikut:

Persentase ketuntasan belajar klasikal $=\frac{\text { jumlah siswa yang tuntas belajar }}{\text { jumlah seluruh siswa }} \times 100 \%$

(dimodifikasi dari Budiati, 2010:55) 


\section{HASIL PENELITIAN DAN PEMBAHASAN}

\section{A. Hasil Penelitian}

1. Paparan Data Siklus I

\section{a. Perencanaan tindakan}

Berdasarkan hasil identifikasi permasalahan yang didapatkan pada tahap observasi awal, dapat diketahui bahwa diperlukan perubahan model pembelajaran. Perubahan dengan model pembelajaran diharapkan dapat meningkatkan pemahaman siswa terhadap pembelajaran PKn pada pokok bahasan globalisasi menjadi lebih baik. Kegiatan pembelajaran pada siklus I ini dilaksanakan sebanyak dua kali pertemuan, yaitu pertemuan 1 pada hari Jumat tanggal 11 maret 2017 dan pertemuan ke-2 hari Jumat 18 maret 2017.

Beberapa hal yang perlu dipersiapkan dalam pembelajaran yang baru, antara lain yaitu:

1) RPP PKn pada pokok bahasan globalisasi dengan menerapkan model pembelajaran kooperatif time token arends.

2) Media pembelajaran yang diperlukan dalam pelaksanaan penelitian serta mempersiapkan materi yang akan disampaikan.

3) Menyiapkan panduan observasi kegiatan guru dan siswa dalam pembelajaran yang menerapkan model pembelajaran kooperatif time token arends.

4) Menyiapkan pedoman wawancara untuk siswa tentang materi pelajaran yang telah disampaikan oleh guru dengan menerapkan model pembelajaran kooperatif time token arends.

5) Menyiapkan post tes dengan pokok bahasan globalisasi.

\section{b. Pelaksanaan Tindakan}

Dalam penelitian ini peneliti bertindak sebagai guru, sedangkan yang bertindak sebagai pengamat yaitu guru lain. Sebelum mengawali kegiatan pembelajaran, terlebih dahulu peneliti memberikan lembar observasi pada pengamat yang bertugas mengamati kegiatan guru (peneliti) dan aktivitas siswa selama pembelajaran. Berdasarkan rencana pembelajaran yang telah disusun, pembelajaran di bagi menjadi empat tahap yaitu: pra kegiatan, kegiatan awal, kegiatan inti dan kegiatan akhir. Pelaksanaan pertemuan ke 1 pada hari Jumat, 11 Maret 2017 dan pertemuan ke -2 pada hari Jumat, 18 Maret 2017.

\section{c. Observasi}

Observasi pada siklus I ini dilaksanakan selama kegiatan pembelajaran berlangsung. Adapun hasilnya adalah sebagai berikut.

\section{1) Pelaksanaan Pembelajaran PKn}

Pembelajaran dengan menerapkan model pembelajaran kooperatif time token arends pada matapelajaran PKn di kelas IV SDN Tunjungtirto 02 Singosari dilaksanakan sesuai RPP yang telah dibuat oleh peneliti bersama guru. Pelaksanaan pembelajaran dilaksanakan dengan tiga tahap. Tahap pertama yaitu kegiatan awal. Pada tahap ini, kegiatan yang dilakukan guru meliputi apersepsi, penyampaian informasi pembelajaran, dan penyampaian tujuan pembelajaran. Tahap kedua yaitu kegiatan inti. Tahap ini merupakan tahap dari pelaksanaan model pembelajaran kooperatif time token arends. Terakhir tahap ketiga yaitu kegiatan akhir. Pada tahap ini, guru memimbing siswa untuk menyimpulkan materi yang telah dipelajari, kemudian dilakukan evaluasi, refleksi, dan diakhiri dengan tindak lanjut. Pada saat pembelajaran berlangsung, peneliti melakukan observasi menggunakan instrumen penelitian berupa APKG 2 untuk guru, sedangkan alat penilaian untuk siswa digunakan instrumen lembar pengamatan aktivitas belajar siswa dengan model pembelajaran kooperatif time token arends. Adapun hasil observasi yang peneliti peroleh adalah sebagai berikut: 


\section{2) Hasil Observasi terhadap Aktivitas Guru selama Pembelajaran Berlangsung}

Pada pelaksanaan siklus I, pertemuan 1 kemampuan guru dalam menerapkan model pembelajaran Siklus Belajar mendapat skor 15 dengan jumlah prosentase sebesar $75 \%$. Pada pertemuan 2 mendapat skor 17 dengan prosentase keberhasilan 85\%. Sehingga jika dihitung ratarata keseluruhan skor dari pertemuan 1 dan pertemuan 2 diperoleh rata-rata sebesar 16 dengan prosentase $80 \%$.

\section{3) Hasil Observasi terhadap Aktivitas Siswa selama Pembelajaran Berlangsung}

Berdasarkan data pada lampiran tersebut diketahui bahwa aktivitas dari pertemuan pertama sampai ke pertemuan kedua mengalami peningkatan dari rata-rata 71,8 menjadi 75,25.

\section{4) Hasil Belajar Siswa}

Dalam pembelajaran yang diadakan setiap pertemuan dilakukan kegiatan evaluasi untuk mengetahui hasil belajar siswa. Data keseluruhan hasil belajar siswa kelas IV pada siklus I dapat dilihat pada tabel 3 .

Tabel 3. Distribusi Frekuensi Hasil Belajar Siklus I

\begin{tabular}{ccc}
\hline Taraf Hasil Belajar & f & \% \\
\hline $81-100$ & 4 & 25 \\
$61-80$ & 12 & 50 \\
$41-60$ & 4 & 25 \\
$21-40$ & - & - \\
$1-20$ & - & - \\
\hline Jumlah & 16 & 100 \\
\hline
\end{tabular}

Dari tabel 3 dapat diketahui rata-rata kelas adalah 72,025. Dimana terdapat 4 siswa mendapatkan skor 81-100 dengan kriteria sangat baik (A), 12 siswa mendapatkan skor 61-80 dengan kriteria baik (B), sedangkan sisanya 4 siswa mendapatkan skor 41-60 dengan kriteria cukup (C). Sedangkan untuk mengetahui prosentase ketuntasan belajar siswa disajikan dalam tabel 4.

Tabel 4. Prosentase Ketuntasan Belajar Siswa Pada Siklus I

\begin{tabular}{crcc}
\hline Ketuntasan Belajar & $\sum$ Siswa & $\sum$ Seluruh Siswa & Prosentase (\%) \\
\hline Tuntas Belajar & 16 & 20 & 80 \\
Belum Tuntas belajar & 4 & 20 & 20 \\
\hline
\end{tabular}

Berdasarkan tabel 4 diketahui bahwa terdapat 20 siswa atau $80 \%$ yang telah mencapai ketuntasan belajar klasikal dan 4 siswa atau sekitar $25 \%$ yang belum mencapai ketuntasan belajar klasikal. Pada siklus I ini hasil belajar siswa mengalami kenaikan dari pada hasil belajar pada pra tindakan. Sedangkan ketuntasan klasikalnya juga mengalami kenaikan yang semula hanya 5 siswa atau

$31,25 \%$ mejadi 16 siswa atau sebesar $80 \%$.

\section{d. Refleksi}

Dari pelaksanaan pembelajaran pada siklus I, peneliti bersama guru kelas lain SDN Tunjungtirto 02 Singosari menemukan beberapa hal yang harus diperbaiki diantaranya:

1) Dalam pelaksanaan pembelajaran, ada beberapa deskriptor yang belum muncul sehingga perlu diperbaiki dengan lebih memperhatikan aspek yang terdapat pada rencana pembelajaran.

2) Sebagian siswa dalam kelompok masih merasa bingung dalam memahami maksud pertanyaan yang terdapat dalam LKS sehingga perlu penyederhanaan dalam penyusunan pertanyaan sehingga mudah dipahami siswa. 
3) Pada saat berdiskusi, sebagian besar siswa sudah dapat melaksanakan dengan baik, namun masih ada beberapa siswa yang masih mengandalkan jawaban dari temannya sehingga guru lebih memberikan motivasi pada siswa untuk bersedia menjawab pertanyaan dengan jawaban sendiri.

4) Sebagian siswa masih merasa kesulitan dalam memberikan tanggapan terhadap hasil pekerjaan temannya sehingga perlu bimbingan dari guru.

5) Terhadap media gambar perlu diperbesar ukurannya agar siswa dapat melihat dengan jelas media gambar yang dibagikan guru.

6) Berdasarkan hasil belajar pada siklus pertama masih perlu ditingkatkan sebab masih di bawah Kriteria Ketuntasan Minimum yang ditetapkan pihak sekolah.

7) Tempat duduk untuk kegiatan berdiskusi dibuat seperti huruf L dan kegiatan siswa lebih diarahkan untuk berkompetisi kelompok dan diberi reward langsung supaya teman satu kelompok bias memotivasi temannya yang pasif berpendapat.

Berdasarkan hasil refleksi pembelajaran siklus I, peneliti bersama guru lain SDN Tunjungtirto.02 Singosari ingin mengadakan perbaikan yang selanjutnya akan dipakai pada siklus yang kedua.

\section{Paparan Data Siklus II}

Pada bagian ini akan di paparkan data yang di peroleh selama tindakan pada siklus I, paparan tersebut meliputi: (a) perencanaan tindakan, (b) pelaksanaan tindakan, (c) observasi dan (d) refleksi. Berikut uraian hasil pembelajaran pada siklus II.

\section{a. Perencanaan tindakan}

Kegiatan yang dilakukan pada tahap perencanaan siklus II sama seperti pada siklus I, yaitu : peneliti bersama guru lain membuat RPP. RPP pada siklus II merupakan pembaharuan dari RPP yang digunakan pada siklus I dengan berpedoman pada kurikulum KTSP, setelah diadakan refleksi untuk mengidentifikasi masalah yang dihadapi guru pada tindakan pembelajaran siklus I.

\section{b. Pelaksanaan Tindakan}

Pelaksanaan pembelajaran pada siklus II ini dilaksanakan selama dua kali pertemuan dengan alokasi setiap pertemuannya adalah 2 x 35 menit. Pertemuan pertama dilaksanakan pada hari Jumat, 25 Maret 2017, pertemuan kedua dilaksanakan pada hari Jumat, 1 April 2017.

\section{c. Observasi}

Observasi pada siklus II ini dilaksanakan selama kegiatan pembelajaran berlangsung. Adapun hasilnya adalah sebagai berikut.

\section{1) Pelaksanaan Pembelajaran PKn}

Pelaksanaan pembelajaran yang dilaksanakan pada siklus II Pertemuan 1 dan 2 adalah sebagai berikut: Pada saat awal pelaksanaan pembelajaran PKn model pembelajaran kooperatif time token arends siswa tenang dan memperhatikan penjelasan guru, namun ketika guru membagi kelompok, kelas menjadi sangat ramai. Siswa ingin mengetahui media yang digunakan oleh guru. Siswa masih penasaran dengan kupon berbicara yang dibagikan oleh guru, disamping itu siswa terlihat masih bingung dengan tata cara penggunaan kupon berbicara yang diberikan oleh guru.

Pembelajaran dengan menerapkan model pembelajaran kooperatif time token arends pada matapelajaran PKn di kelas IV SDN Tunjungtirto.02 Singosari dilaksanakan sesuai RPP yang telah dibuat oleh peneliti bersama guru lain. Pelaksanaan pembelajaran dilaksanakan dengan tiga tahap. Tahap pertama yaitu kegiatan awal. Pada tahap ini, kegiatan yang dilakukan guru meliputi apersepsi, penyampaian informasi pembelajaran, dan penyampaian tujuan pembelajaran. Tahap kedua yaitu kegiatan inti. Tahap ini merupakan tahap dari pelaksanaan model pembelajaran kooperatif time token arends. Terakhir tahap ketiga yaitu kegiatan akhir. Pada tahap ini, guru 
memimbing siswa untuk menyimpulkan materi yang telah dipelajari, kemudian dilakukan evaluasi, refleksi, dan diakhiri dengan tindak lanjut. Pada saat pembelajaran berlangsung, peneliti melakukan observasi menggunakan instrumen penelitian berupa APKG 2 untuk guru, sedangkan alat penilaian untuk siswa digunakan instrumen lembar pengamatan aktivitas belajar siswa dengan model pembelajaran kooperatif time token arends. Adapun hasil observasi yang peneliti peroleh adalah sebagai berikut:

\section{1) Hasil Observasi terhadap Aktivitas Guru selama Pembelajaran Berlangsung}

Berdasarkan data observasi, dapat diketahui bahwa pelaksanaan siklus II pertemuan 1 kemampuan guru dalam menerapkan model pembelajaran kooperatif time token arends mendapat skor 20 dengan jumlah prosentase sebesar 90\%. Pada pertemuan 2 mendapat skor 21 dengan prosentase keberhasilan 95\%. Sehingga dapat disimpulkan bahwa proses aktivitas guru telah sesuai dengan rencana pelaksanaan pembelajaran yang direncanakan sebelumnya.

\section{2) Hasil Observasi terhadap Aktivitas Siswa selama Pembelajaran Berlangsung}

Berdasarkan data pada kedua lampiran tersebut diketahui bahwa aktivitas dari pertemuan pertama sampai ke pertemuan kedua mengalami peningkatan dari rata-rata 80,75 menjadi 81,5

\section{3) Hasil Belajar Siswa}

Dalam pembelajaran yang diadakan setiap pertemuan dilakukan kegiatan evaluasi untuk mengetahui hasil belajar siswa. Data keseluruhan hasil belajar siswa kelas IV pada siklus II dapat dilihat pada tabel 5 .

\begin{tabular}{ccc}
\multicolumn{3}{c}{ Tabel 5. Distribusi Frekuensi Hasil Belajar Siklus II } \\
\hline Taraf Hasil Belajar & f & \% \\
\hline $81-100$ & 7 & 37,5 \\
$61-80$ & 11 & 50 \\
$41-60$ & 2 & 12,5 \\
$21-40$ & - & - \\
$1-20$ & - & - \\
\hline Jumlah & 20 & 100 \\
\hline
\end{tabular}

Dari tabel 5, dapat diketahui rata-rata kelas adalah 76,88 Dimana terdapat 7 siswa mendapatkan skor 81-100 dengan kriteria sangat baik (A), 11 siswa mendapatkan skor 61-80 dengan kriteria baik (B) serta 2 siswa mendapatkan skor 41-60 dengan kriteria cukup (C). Sedangkan untuk mengetahui prosentase ketuntasan belajar siswa disajikan dalam tabel 6.

Tabel 6. Prosentase Ketuntasan Belajar Siswa Pada Siklus II

\begin{tabular}{crcc}
\hline Ketuntasan Belajar & $\sum$ Siswa & $\sum$ Seluruh Siswa & Prosentase (\%) \\
\hline Tuntas Belajar & 18 & 20 & 90 \\
Belum Tuntas belajar & 2 & 20 & 10 \\
\hline
\end{tabular}

Berdasarkan tabel 6 diketahui bahwa terdapat 14 siswa atau 87,5\% yang telah mencapai ketuntasan belajar klasikal, sedangkan sisanya 2 siswa atau 12,5\% belum mencapai ketuntasan belajar klasikal. Pada siklus II ini hasil belajar siswa mengalami kenaikan dari hasil belajar pada pra tindakan dan siklus I.

\section{d. Refleksi}

Dari pelaksanaan pembelajaran pada siklus II hampir seluruh siswa senang dan antusias dalam mengikuti pembelajaran Pkn yang menerapkan model pembelajaran kooperatif time token arends. 
1) Guru sudah melaksanakan pembelajaran sesuai dengan RPP.

2) Aktivitas siswa sudah meningkat sebab mulai dari siklus I sampai siklus II mengalami peningkatan, hal ini terlihat dari kerjasama siswa dalam kelompok dalam menyelesaikan LKS.

3) Keberanian siswa dalam mengajukan pertanyaan dan menyampaikan pendapat sudah tampak terlihat.

4) Hasil belajar siswa sudah menunjukkan peningkatan di atas KKM yang telah ditentukan pihak sekolah meskipun masih ada beberapa siswa yang belum tuntas belajar, hal ini dikarenakan inteligensi yang dimiliki siswa masih kurang sehingga memiliki prestasi belajar yang rendah.

5) Indikator keberhasilan yang ditentukan dalam penelitian ini sudah tercapai, sehingga peneliti menghentikan siklus karena peneliti merasa target yang ingin dicapai telah tercapai sesuai Kompetensi Dasar yang ditentukan.

\section{B. Pembahasan \\ 1. Siklus I}

Berdasarkan pengamatan yang telah dilakukan selama pelaksanaan siklus I, maka diperoleh beberapa temuan diantaranya: Pelaksanaan pembelajaran dilaksanakan dengan tiga tahap. Tahap pertama yaitu kegiatan awal. Pada tahap ini, kegiatan yang dilakukan guru meliputi apersepsi, penyampaian informasi pembelajaran, dan penyampaian tujuan pembelajaran. Tahap kedua yaitu kegiatan inti. Tahap ini merupakan tahap dari pelaksanaan pembelajaran. Tahap ketiga yaitu kegiatan akhir. Pada tahap ini, guru memimbing siswa untuk menyimpulkan materi yang telah dipelajari, kemudian dilakukan evaluasi, refleksi, dan diakhiri dengan tindak lanjut. Sebagai kegiatan yang bertujuan untuk menilai keberhailan siswa, evaluasi memegang peranan yang sangat penting. Sebab, melalui evaluasi guru dapat menentukan apakah siswa yang telah mengikuti pelajaran tersebut sudah memiliki kompetensi yang telah ditetapkan, sehingga mereka layak diberikan program pembelajaran baru; atau malah sebaliknya siswa belum mampu mencapai standart ketuntasan minimal.

Berdasarkan data yang diperoleh pada siklus dapat diketahui bahwa pada pelaksanaan siklus I pertemuan 1 kemampuan guru dalam menerapkan model pembelajaran Kooperatif time token arends mendapat skor 15 dengan jumlah prosentase sebesar 75\%. Pada pertemuan 2 mendapat skor 17 dengan prosentase keberhasilan 85\%. Sehingga jika dihitung rata-rata keseluruhan skor dari pertemuan 1 dan pertemuan 2 diperoleh rata-rata sebesar 16 dengan prosentase $80 \%$ data selengkapnya dapat dilihat pada lampiran 15 dan 16 . Pada siklus I ini hasil belajar siswa mengalami kenaikan dari pada hasil belajar pada pra tindakan. Sedangkan ketuntasan klasikalnya juga mengalami kenaikan yang semula hanya 5 siswa atau 31,25\% mejadi 16 siswa atau sebesar $80 \%$.

\section{Siklus II}

Berdasarkan pengamatan yang telah dilakukan selama pelaksanaan siklus I, maka diperoleh beberapa temuan diantaranya: Pelaksanaan pembelajaran dilaksanakan dengan tiga tahap. Tahap pertama yaitu kegiatan awal, kegiatan inti dan kegiatan akhir. Berdasarkan data pada Siklus II dapat diketahui bahwa pelaksanaan siklus II pertemuan 1 kemampuan guru dalam menerapkan model pembelajaran kooperatif time token arends mendapat skor 21 dengan jumlah prosentase sebesar 95\%. Pada pertemuan 2 mendapat skor 20 dengan prosentase keberhasilan 90\% data selengkapnya dapat dilihat pada lampiran 19 dan 20. Sehingga dapat disimpulkan bahwa proses aktivitas guru telah sesuai dengan rencana pelaksanaan pembelajaran yang direncanakan sebelumnya . 
Berdasarkan data yang diperoleh pada siklus II diketahui bahwa terdapat 18 siswa atau 90 $\%$ yang telah mencapai ketuntasan belajar klasikal, sedangkan sisanya 2 siswa atau $10 \%$ belum mencapai ketuntasan belajar klasikal. Pada siklus II ini hasil belajar siswa mengalami kenaikan dari hasil belajar pada pra tindakan dan siklus I data selengkapnya dapat dilihat pada tabel 6 . Berdasarkan data yang diperoleh dapat diketahui bahwa bahwa penerapan model pembelajaran kooperatif time token arends dapat meningkatkan aktivitas hasil belajar siswa dan dapat mengembangkan keterampilan proses dalam pembelajaran PKn. Peneliti menghentikan siklus, karena peneliti merasa proses pembelajaran dengan model pembelajaran kooperatif time token arends telah berjalan dengan baik sesuai dengan langkah-langkah pembelajaran dalam model pembelajaran kooperatif time token arends, selain itu hasil belajar yang akan dicapai telah berhasil mencapai ketuntasan belajar yang telah ditetapkan. Hal tersebut dapat di buktikan dengan adanya peningkatan aktivitas dan hasil belajar yang diperoleh setelah penerapan model pembelajaran kooperatif time token arends yang di bahas bada bab-bab sebelumnya.

\section{Penerapan Model Pembelajaran Kooperatif Time Token Arends pada Mata Pelajaran PKn di Kelas IV SDN Tunjungtirto 02 Singosari}

Penerapan dari model pembelajaran kooperatif time token arends pada pelajaran PKn selama pelaksanaan tindakan, siswa tidak hanya menerima pengetahuan secara langsung dari guru seperti yang terjadi sebelumnya pada saat dilaksanakan pratindakan. Siswa dalam kegiatan pembelajaran lebih banyak memperoleh pengetahuan secara langsung dengan cara mendengar ceramah guru. Siswa lebih banyak "diberi tahu" dari pada dibimbing untuk "mencari tahu". Hal tersebut menyebabkan kondisi siswa tidak aktif dalam pembelajaran misalnya untuk mengemukakan pendapat. Pembelajaran kooperatif time token arends selama pelaksanaan tindakan membantu siswa dalam mengutarakan pedapatnya, siswa menjadi aktif berpendapat dan frekuensi siswa yang berpendapat di kelas lebih merata hal ini sesuai dengan pendapat Lie (2010:31) model pembelajaran adalah model pembelajaran yang lebih menekankan pada keaktifan siswa dalam mengutarakan pendapatnya mengenai suatu masalah yang muncul. Pemahaman tentang materi oleh siswa dalam model ini sangat diutamakan terutama dalam bentuk diskusi yang kebanyakan pendapatnya harus memiliki dasar yang kuat untuk sebuah argumen. Model pembelajaran ini dapat membantu siswa untuk mengutarakan pendapatnya dengan merata membantu ketrampilan sosial dengan cara menghargai pendapat dari siswa yang lain sehingga kegiatan pembelajaran yang dilakukan sesuai dengan tujuan dari pembelajaran PKn menurut Mulyasa (dalam Ruminiati, 2008:26) tujuan PKn yaitu agar dapat berkembang secara positif dan demokratis, sehingga mampu hidup bersama dengan bangsa lain di dunia.

Pembelajaran dengan menerapkan model pembelajaran kooperatif time token arends pada matapelajaran PKn di kelas IV SDN Tunjungtirto.02 dilaksanakan sesuai RPP yang telah dibuat oleh peneliti bersama guru. Pelaksanaan pembelajaran dilaksanakan dengan tiga tahap. Tahap pertama yaitu kegiatan awal. Pada tahap ini, kegiatan yang dilakukan guru meliputi apersepsi, penyampaian informasi pembelajaran, dan penyampaian tujuan pembelajaran.

Tahap kedua yaitu kegiatan inti. Tahap ini merupakan tahap dari pelaksanaan pelaksanaan model pembelajaran kooperatif time token arends. Langkah-langkah permainan pembelajaran yang dilakukan adalah sebagai berikut: (a) guru menjelaskan tujuan pembelajaran dan menyajikan materi, (b) membentuk siswa menjadi kelompok dan melakukan diskusi, (c) guru membegikan kupon berbicara, (d) memperkenalkan siswa terhadap aturan pembelajaran, (e) pelaksanaan diskusi dengan menggunakan kupon berbicara, (f) siswa yang sudah berbicara menyerahkan kupon kepada guru, (g) kesimpulan dan saran. 
Hal ini sesuai dengan pendapat Yuanita (2010:1) langkah-langkah model pembelajaran kooperatif time token arends:

a. Guru menjelaskan tujuan pembelajaran atau kompetensi dasar.

b. Guru mengkondisikan kelas untuk melaksanakan diskusi (cooperative learning / CL).

c. Guru memberikan setiap siswa kupon berbicara dengan waktu yang ditentukan (biasanya 30 detik-1 menit), dan setiap siswa diberi sejumlah nilai sesuai waktu yang ditentukan.

d. Bila telah selesai bicara kupon yang dipegang siswa deserahkan pada guru. Setiap berbicara satu kupon.

e. Siswa yang telah habis kuponnya tidak boleh bicara lagi, dan siswa yang lain yang masih memegang kupon harus bicara sampai kuponnya habis.

f. Sehingga semua siswa memiliki hak bicara yang sama, dan sampai semua siswa berbicara ( berpendapat).

g. Guru dan siswa membuat kesimpulan bersama dari hasil diskusi.

h. Guru menutup pelajaran.

Tahap ketiga yaitu kegiatan akhir. Pada tahap ini, guru memimbing siswa untuk menyimpulkan materi yang telah dipelajari, kemudian dilakukan evaluasi, refleksi, dan diakhiri dengan tindak lanjut. Sebagai kegiatan yang bertujuan untuk menilai keberhailan siswa, evaluasi memegang peranan yang sangat penting. Sebab, melalui evaluasi guru dapat menentukan apakah siswa yang telah mengikuti pelajaran tersebut sudah memiliki kompetensi yang telah ditetapkan, sehingga mereka layak diberikan program pembelajaran baru; atau malah sebaliknya siswa belum mampu mencapai standart ketuntasan minimal. Hasil penelitian menunjukkan bahwa dari siklus I kemampuan guru dalam tindakan pembelajaran mendapat skor akhir 85 dengan kriteria nilai baik. Hasil dari siklus I mengalami peningkatan lagi pada siklus II dengan skor 95 dengan kriteria sangat baik.

Hasil yang ditunjukkan mulai dari skor yang diperoleh pada siklus I dan meningkat lagi pada siklus II membuktikan bahwa dengan menerapkan model pembelajaran kooperatif time token arends pada matapelajaran PKn di kelas IV SDN Tunjungtirto 02 dapat mendongkrak kemampuan guru dalam mengajar, sehingga guru berhasil meningkatkan mutu guru dan mencari solusi yang tepat bagi pengembang pendidikan yang lebih baik. Guru dapat mengelola kelas dengan baik, mampu menempatkan diri kapan guru harus berpartisipasi secara langsung dalam kegiatan pembelajaran. Hal ini sesuai dengan pendapat Corey (dalam Ruminiati, 2008:14) mengartikan pembelajaran adalah suatu proses dimana lingkungan seseorang dikelola secara disengaja untuk memungkinkan ia turut serta dalam tingkah laku tertentu, sehingga dalam kondisi-kondisi khusus akan menghasilkan respons terhadap situasi tertentu.

\section{Peningkatan Hasil Belajar dengan Menerapan Model Pembelajaran Kooperatif Time Token Arends pada Mata pelajaran PKn di Kelas IV SDN Tunjungtirto 02}

Pada pembelajaran sebelum penerapan model pembelajaran kooperatif time token arends dapat diketahui bahwa rata-rata nilai kelas dari 20 siswa adalah 57,37 dan masih ada 13 siswa $(68,75 \%)$ belum mencapai ketuntasan belajar individu yang telah ditetapkan yaitu 65 . Hal ini berarti hanya 7 siswa $(31,25 \%)$ saja yang telah mencapai ketuntasan belajar individu. Ketuntasan belajar kelas minimal $80 \%$ telah tercapai. Skor post tes siklus I yang diperoleh siswa meningkat, dapat diketahui bahwa terdapat 16 siswa atau $80 \%$ yang telah mencapai ketuntasan belajar klasikal yng ditetapkan yaiti 65 dan 4 siswa atau sekitar 20\% yang belum mencapai ketuntasan belajar klasikal yang ditetapkan oleh sekolah. Sebagian besar siswa yang belum mencapai ketuntasan belajar diduga dikarenakan beberapa hal (berdasarkan temuan peneliti) diantaranya: (a) 
pembelajaran yang terjadi tidak melibatkan siswa secara langsung dalam pembelajaran (siswa pasif), sehingga menyebabkan siswa mudah lupa dan bahkan kurang memahami materi; (b) selama pembelajaran tidak pernah diadakan diskusi kelompok, sehingga kurang menggali kemampuan siswa; (c) pembelajaran yang masih berpusat pada guru, sehingga dapat menyebabkan siswa mengantuk, tidak konsentrasi dan bahkan mengalihkan perhatiannya pada kegiatan diluar pembelajaran seperti bermain-main buku sendiri; (d) dalam pembelajaran siswa bekerja secara individu sehingga sebagian besar siswa hanya pasif dalam menerima pelajaran dari guru, ada juga sebagian kecil yang menanggapi materi yang di berikan oleh guru dengan bertanya kepada gurunya, akan tetapi kondisi yang demikian mengakibatkan kegiatan pembelajaran tidak merata, hanya tiga sampai empat siswa yang ikut aktif dalam kegiatan pembelajaran, siswa yang aktif tersebut selalu mendominasi kelas. Temuan diatas dapat di antisipasi dengan pendapat Arends (2008:29) Time tokens adalah kegiatan-kegiatan khusus yang mengajarkan keterampilan partisipasi. Apabila seorang guru memiliki kelompok-kelompok cooperatife learning dengan beberapa orang mendominasi pembicaraan dan beberapa orang pemalu dan tidak pernah mengatakan apa-apa, time tokens dapat mendistribusikan pertisipasi dengan lebih merata.

Pada pelaksanaan pembelajaran siklus II dapat diketahui bahwa terdapat 18 siswa atau 90 $\%$ yang telah mencapai ketuntasan belajar klasikal, sedangkan sisanya 2 siswa atau $10 \%$ belum mencapai ketuntasan belajar klasikal. Siswa yang belum berhasil yaitu Rizky dan imam, mereka adalah tergolong siswa yang slow learner (lambat ajar). Rizky cenderung diam dan Imam selalu asyik bermain sendiri pada saat pembelajaran berlangsung. Ketuntasan belajar kelas pada siklus II dengan demikian sudah tercapai yaitu minimal $80 \%$.

Meningkatnya hasil belajar siswa kelas IV SDN Tunjungtirto 02 dengan model pembelajaran kooperatif time token arends, bukan berarti pembelajaran dengan model pembelajaran kooperatif time token arends ini tidak memiliki kelemahan. Pembelajaran dengan model pembelajaran kooperatif time token arends yang dilaksanakan di SDN Tunjungtirto.02 juga memiliki kelemahan, yaitu siswa yng memiliki pendapat banyak tidak dapat mengkontribusikan semua pendapatnya di dalam kelas, sehingga proses Pembelajaran tidak berhasil secara maksimal.

Kelemahan dalam pembelajaran dengan model pembelajaran kooperatif time token arends bukan berarti pembelajaran tersebut tidak layak untuk diterapkan, tetapi harus dicari solusi pemecahannya. Adapun solusi yang dapat digunakan untuk mengatasi kelemahan tersebut yaitu diharapkan guru bisa memberikan pengertian dan motivasi kepada siswa bahwa belajar dengan menggunakan model pembelajaran kooperatif time token arends merupakan pembelajaran yang menyenangkan.

\section{PENUTUP}

Berdasarkan hasil penelitian dan pembahasan yang telah disajikan pada bab sebelumnya, maka dapat disimpulkan beberapa hal yaitu:

1. Pembelajaran dengan menerapkan model pembelajaran kooperatif time token arends pada matapelajaran PKn di kelas IV SDN Tunjungtirto.02 dilaksanakan sesuai RPP yang telah dibuat oleh peneliti bersama guru. Pelaksanaan pembelajaran dilaksanakan dengan tiga tahap. Tahap pertama yaitu kegiatan awal. Pada tahap ini, kegiatan yang dilakukan guru meliputi apersepsi, penyampaian informasi pembelajaran, dan penyampaian tujuan pembelajaran. Tahap kedua yaitu kegiatan inti. Tahap ini merupakan tahap dari pelaksanaan pelaksanaan model pembelajaran kooperatif time token arends. Langkah-langkah pembelajaran yang dilakukan adalah sebagai berikut: (a) guru menjelaskan tujuan pembelajaran dan menyajikan materi, (b) membentuk siswa menjadi kelompok dan melakukan diskusi, (c) guru membegikan 
kupon berbicara, (d) memperkenalkan siswa terhadap aturan pembelajaran, (e) pelaksanaan diskusi dengan menggunakan kupon berbicara, (f) siswa yang sudah berbicara menyerahkan kupon kepada guru, (g) kesimpulan dan saran. Tahap ketiga yaitu kegiatan akhir. Pada tahap ini, guru memimbing siswa untuk menyimpulkan materi yang telah dipelajari, kemudian dilakukan evaluasi, refleksi, dan diakhiri dengan tindak lanjut.

2. Berdasarkan penerapan model pembelajaran kooperatif time token arends pada matapelajaran PKn dikelas IV SDN Tunjungtirto.02 pada pokok bahasan Globalisasi dapat meningkatkan hasil belajar siswa kelas IV SDN Tunjungtirto.02.

\section{DAFTAR RUJUKAN}

Akbar, Sa'dun. 2009. Penelitian Tindakan Kelas Filosofi, Metodologi \& Implementasinya. Yogyakarta: Cipta Media Aksara.

Arends, Ricard I. 2008. Learning to Teach (edisi ke-7). Yogyakarta: Pustaka Pelajar.

Arikunto, Suharsimi. 2009. Dasar-Dasar Evaluasi Pendidikan. Jakarta: Bumi Aksara.

Depdiknas, 2006. Peraturan Menteri Pendidikan Nasional Republik Indonesia Nomor 22 Tahun 2006 Tentang Standar Isi untuk Satuan Pendidikan Dasar dan Menengah. Jakarta: Departemen Pendidikan Nasional.

Depdiknas. 2007. Model Kurikulim Tingkat Satuan Pendidikan SD/MI (KTSP). Solo: Tiga Serangkai Pustaka Mandiri.

Dimyati dan Mujdiono . 2006. Belajar dan Pembelajaran. Jakarta: PT Rineka Cipta

Fajriah, Lailatul. 2009. Penggunaan Metode Simulasi untuk Meningkatkan Hasil Belajar Siswa Kelas V di SDN Sidorejo 02 Pagelaran-Malang pada Matapelajaran PKn. Skripsi tidak diterbitkan. Malang: FIP Universitas Negeri Malang

Hamalik, Oemar. 2010. Kurikulum dan Pembelajaran. Jakarta: Bumi Aksara

Hanafiah dan Sujana. 2009. Konsep Strategi Pembelajran. Bandung: PT Refika Aditama

Isjoni. 2010. Cooperative Learning Efektivitas Pembelajaran Kelompok. Bandung: CV Alfabeta.

Lie, Anita. 2010. Cooperative Learning Di Kelas Kita. Jakarta: Grassindo.

Ruminiati. 2008. Pengembangan PKn SD. Jakarta: Dikti Depdiknas.

Suharjo. 2006. Mengenal Pendidikan Sekolah Dasar. Jakarta: Direktorat Jendral Pendidikan Tinggi.

Suprijono, Agus. 2010. Cooperative Learning Teori dan Aplikasi PAIKEM. Yogyakarta: Pustaka Pelajar.

Suyatno. 2009. Menjelajah Pembelajaran Inovatif. Sidoarjo: Masmedia Buana Pustaka.

Widodo, Rachmad. 2010. Model Pembelajaran Time Token Arends. Rachmadwidodo's, (Online), (http://wyw1d.wordpress.com/2009/11/14/model-pembelajaran-time-token-arends1998/), diakses 10 Januari 2011.

Yuanita, Eva. 2010. Model Pembelajaran Time Token Arends. RHUM4H ND3SO Q, (Online), ( http://rhum4hnd3soq.blogspot.com/2010/11/model-pembelajaran-time-tokenarends.html), diakses 10 Januari 2011. 
AL-ADZKA, Jurnal Ilmiah Pendidikan Guru Madrasah Ibtidaiyah Volume VIII, Nomor 01, Hal (1-15) Juni 2018 